\title{
EKSTRAKSI Y, Dy, Gd DARI KONSENTRAT ITRIUM DENGAN SOLVEN TBP DAN D2EHPA
}

\section{EXTRACTION OF Y, Dy, Gd FROM YTTRIUM CONCENTRATE BY TBP AND D2EHPA SOLVENTS}

\author{
Tri Handini*, Bambang EHB, Sri Sukmajaya \\ Pusat Sains dan Teknologi Akselerator, BATAN \\ Jl. Babarsari Kotak Pos 6101 Yogyakarta 55281 \\ *e-mail: handini@batan.go.id
}

Diterima 29 September 2016, diterima dalam bentuk perbaikan 12 April 2017, disetujui 14 April 2017

\begin{abstract}
ABSTRAK
EKSTRAKSI Y, Dy, Gd DARI KONSENTRAT ITRIUM DENGAN SOLVEN TBP DAN D2EHPA. Telah dilakukan pemisahan itrium (Y), disprosium (Dy), dan gadolinium (Gd) dari konsentrat itrium hasil olah pasir senotim dengan cara ekstrasi cair-cair. Pasir senotim adalah sumber logam tanah jarang dengan kandungan utama itrium. Solven yang akan digunakan untuk proses ekstraksi yaitu tri butil phosphat (TBP) dan bis(2ethylhexyl) phosphate (D2EHPA) dalam pengencer kerosen. Umpan ekstraksi adalah konsentrat itrium yang dilarutkan dalam suasana asam nitrat. Penentuan kadar Y, Dy, dan Gd dianalisis menggunakan alat pendar sinar-X. Tujuan penelitian ini adalah untuk memperoleh pemisahan itrium yang relatif murni. Pada proses ekstraksi pemisahan Y, Dy, dan Gd, variabel yang berpengaruh antara lain : konsentrasi asam nitrat dalam larutan umpan, waktu ekstraksi, perbandingan umpan dan solven. Dari hasil percobaan diperoleh kondisi terbaik adalah keasaman umpan 0,5 M, waktu ekstraksi 15 menit, kecepatan pengadukan $250 \mathrm{rpm}$, solven $30 \%$ D2EHPA dengan pengencer kerosin, perbandingan fasa air $(F A)$ : fasa organik $(F O)=1: 1$. Pada kondisi ini diperoleh harga faktor pisah Y-Dy =22,576 dan Y-Gd=59,2.
\end{abstract}

Kata kunci: Ekstraksi, konsentrat itrium, TBP, D2EHPA

\begin{abstract}
EXTRACTION OF Y, Dy, Gd FROM YTTRIUM CONCENTRATE BY TBP AND D2EHPASOLVENT. Separation of yttrium (Y), dysprosium (Dy), and gadolinium (Gd) by liquid-liquid extraction have been done from the yttrium concentrate processed result of senotim sand. Senotim sand is a source of rare earth elements with the main content of yttrium. Solvents that used for the extraction processes were tri butil phosphate (TBP) and bis(2-ethylhexyl) phosphate (D2EHPA) in kerosene diluent. The extraction feed was $Y$ concentrates disolved in nitric acid. Determination of $Y, D y$, and $G d$ were analyzed using $X$-ray fluorescent. The purpose of this study was to obtain the relatively pure separated of yttrium. In the separation extraction process of $Y, D y$, and $G d$, the influent variables were: the concentration of nitric acid in the feed solution, the extraction time, the ratio of the feed and the organic phase and concentration of the solvent in the organic phase. From the experiments was obtained the best result with conditions of acidity feed of $0.5 \mathrm{M}$, extraction time of 15 minutes, stirring speed of $250 \mathrm{rpm}$, solvent 30\% D2EHPA in kerosene diluent, ratio aquous (FA): inorganic phase $(F O)=1: 1$. In this condition the separation factor obtained for Y-Dy and Y-Gd were 22.576 and 59.292 respectively.
\end{abstract}

Keywords: Extraction, Concentrate Yttrium, TBP, D2EHPA

\section{PENDAHULUAN}

Dasir senotim biasa ditulis dengan rumus molekul $\mathrm{LTJPO}_{4}$ atau $\mathrm{YPO}_{4}$ adalah merupakan salah satu mineral yang mengandung logam tanah jarang (Y, Dy, Gd, La, Ce, Nd). Pasir senotim banyak terdapat di pulau Bangka, Singkep, dan Belitung. Biasanya pasir ini digunakan sebagai salah satu sumber untuk mendapatkan logam itrium (Y) [1].

Logam tanah jarang (LTJ) atau (rare earth elements, REEs) dikenal sebagai lantanida dalam susunan berkala unsur-unsur, memiliki nomor atom antara 57 sampai 71 . Ada 15 unsur yang termasuk dalam kelompok 
ini, yaitu lantanum $(\mathrm{La})$, serium $(\mathrm{Ce})$, praseodimium $(\mathrm{Pr})$, neodimium $(\mathrm{Nd}$, promotium $(\mathrm{Pm})$ samarium $(\mathrm{Sm})$, europium ( $\mathrm{Eu}$ ), gadolinium (Gd), terbium (Tb), disprosium (Dy), holmium ( $\mathrm{Ho})$, erbium (Er), talium (Tm), iterbium $(\mathrm{Yb})$, dan lutesium (Lu). Walaupun skandium (Sc) yang nomor atomnya 21 dan $\mathrm{Y}$ nomor atom 39 sebenarnya bukan lantanida, tetapi karena di alam terdapat bersama-sama lantanida dan memiliki sifat-sifat kimia dan fisika yang mirip, maka digolongkan sebagai LTJ [1-7]. Karena sifat-sifatnya yang mirip, maka di dalam pemisahan dari mineral induknya sangat sulit. Logam tanah jarang mempunyai sifat kimia dan fisika yang unik sehingga merupakan unsur-unsur logam yang esensial sehingga banyak dipakai dalam teknologi tinggi baik industri nuklir dan non nuklir. Basnaesit ( $\mathrm{La}, \mathrm{Ce}) \mathrm{FCO}_{3}$, monasit ( $\left.\mathrm{Ce}, \mathrm{La}, \mathrm{Y}, \mathrm{Th}\right) \mathrm{PO}_{4}$, dan senotim $\left(\mathrm{YPO}_{4}\right)$ adalah sumber utama komersial dari LTJ [8-10].

Indonesia terutama di pulau Bangka, Belitung, dan Singkep mempunyai sumber logam tanah jarang dalam bentuk pasir monasit dan senotim yang merupakan hasil samping penambang PT. Timah Tbk. di Bangka [9]. Itrium (Y) merupakan unsur logam tanah jarang (LTJ) yang banyak terkandung dalam pasir senotim, di samping unsur-unsur lain seperti disprosium (Dy), gadolinium (Gd), samarium ( $\mathrm{Sm}$ ), lantanum (La), serium (Ce), dan neodimium $(\mathrm{Nd})$. Itrium dalam bentuk oksida $\left(\mathrm{Y}_{2} \mathrm{O}_{3}\right)$ digunakan sebagai bahan tabung reaktor, televisi berwarna, keramik, superkonduktor, laser, magnetik, sel bahan bakar oksida padat Solid Oxide Fuel Cell (SOFC), filter gelombang mikro, dan lain-lain [10].

Secara umum dapat dikatakan bahwa karena $Y$ dan LTJ merupakan bahan unggul strategis-ekonomis, sukar diperoleh, dan kegunaannya sangat banyak, baik dibidang nuklir maupun non nuklir, maka banyak dipakai di bidang teknologi moderen (high tech, green energy) [5].

Mengingat prospek, potensi, dan nilai ekonomi yang sangat besar, maka usaha-usaha untuk mendapatkan Y sebanyak-banyaknya sangat diperlukan. Dengan dasar pertimbangan tekno-ekonomis, maka perlu dipilih teknologi yang paling feasible dan efisien untuk memperoleh $Y$ maksimal pada kisaran kondisi operasi yang dikehendaki [9].

Proses pemisahan dan pemurnian individual itrium (Y) dan logam tanah jarang (LTJ) dapat dilakukan antara lain dengan cara pengendapan, kristalisasi, ekstraksi cair-cair, dan kromatografi pertukaran ion [1,9]. Dari berbagai metode pemisahan LTJ tersebut, secara umum dipakai proses ekstraksi. Ekstraksi cair-cair banyak dikerjakan karena relatif lebih sederhana, efisien dan lebih cepat dibandingkan teknik yang lain [11]. Palakorn, (2015) melakukan pemisahan LTJ ringan dan LTJ berat dengan ekstraktan TBP diencerkan dengan diluen kerosen menggunakan umpan larutan logam tanah jarang nitrat [3]. Sato, (1984) melakukan ekstraksi dari campuran uranil khlorida dan itrium khlorida pada berbagai variasi asam menggunakan ekstraktan D2EHPA (diester) dan D2EHPA (mono \& diester) dalam kerosen pada suhu $20-30{ }^{\circ} \mathrm{C}$. Hasil ekstraksi diperoleh larutan yang baik pada keasaman yang rendah [11].

Proses ekstraksi solven untuk pemisahan dan pemurnian dari campuran LTJ terus dilakukan melalui litbang dengan tujuan untuk mendapatkan ekstraktan yang selektif. Mengingat kecenderungan kebutuhan LTJ yang semakin meningkat karena besarnya manfaat LTJ dalam industri nuklir dan non nuklir di dunia dan potensi $Y$ dalam kandungan pasir senotim, maka perlu dilakukan penelitian dalam segi proses untuk pemisahan dan pemurnian menggunakan konsentrat LTJ senotim hasil olah pasir senotim untuk menghasilkan Y khususnya dan LTJ pada umumnya.

Tujuan dari penelitian ini adalah untuk memperoleh pemisahan itrium ( $Y$ ), disprosium (Dy), dan gadolinium (Gd) dari umpan konsentrat itrium hasil olah pasir senotim. Hasil penelitian yang diharapkan, dapat diperoleh kondisi optimum pada proses ekstraksi cair-cair memakai solven TBP dan D2EHPA dari umpan konsentrat itrium dalam suasana asam.

Ekstraktan yang bisa digunakan untuk ekstraksi LTJ antara lain TBP, D2EHPA, dan TOPO [1]. Pengencer yang dapat digunakan antara lain: dodekan, kerosen dan n-heptan. Pada penelitian ini dipakai D2EHPA dengan pengencer dodekan memakai umpan konsentrat logam tanah jarang hasil olah pasir senotim. Pemakaian D2EHPA pada industri semakin luas digunakan untuk ekstraksi karena mempunyai selektivitas dan efisiensi yang tinggi $[9,11,13]$.

Umpan untuk proses ekstraksi dibuat dalam suasana asam nitrat $[4,6,11,12]$. Pada keadaan setimbang nilai koefisien distribusi $Y\left(K d_{Y}\right)$ dapat dihitung dengan cara perbandingan konsentrasi $Y$ dalam fasa organik (ekstrak) dibagi konsentrasi $Y$ dalam fasa air (rafinat). Koefisien distribusi dinyatakan dengan rumus sebagai berikut [4]: 
$K d y=\frac{C_{E}}{C_{R}}$

Dengan $C_{E}$ adalah konsentrasi $Y$ dalam fasa organic dan $C_{R}$ adalah konsentrasi $Y$ dalam fasa air.

Ukuran yang dipakai untuk menilai keberhasilan suatu proses ekstraksi sering pula digunakan suatu besaran berupa faktor pisah $(F P)$ yakni perbandingan antara koefisien distribusi unsur $(Y)$ dengan koefisien distribusi LTJ. Faktor pisah ( $\beta$ ) dapat dinyatakan dengan persamaan sbb [6,7]:

$$
F P=\beta=\frac{K d_{Y}}{K d_{L T J}}
$$

\section{METODOLOGI}

Alat

Alat yang digunakan adalah peralatan gelas laboratorium, timbangan, pengaduk dan pemanas (lkamag), alat spektrometer pendar sinar $-\mathrm{X}$ (MCA ORTEC, $\mathrm{hV}=50 \mathrm{eV}$, sumber ${ }^{241} \mathrm{Am}$, waktu cacah $=300$ detik).

Bahan

Konsentrat itrium (PSTA), $\mathrm{HNO}_{3} 65$ \% (Merck), TBP (Merck), D2EHPA (Merck), Kerosin (Fisher).

\section{Cara Kerja}

\section{Variasi konsentrasi umpan}

Dibuat umpan ekstraksi 0,5 gram konsentrat itrium yang dilarutkan dalam $25 \mathrm{~mL}$ asam nitrat yang divariasi keasamannya yaitu 0,$2 ; 0,5 ; 1,2,3$, dan $4 \mathrm{M}$. Proses ekstraksi dilakukan dengan cara mengambil masing-masing $10 \mathrm{~mL}$ umpan ditambah $10 \mathrm{~mL}$ solven 30\% TBP-Kerosin, waktu ekstraksi 15 menit, pengadukan pada kecepatan $250 \mathrm{rpm}$, perbandingan FA:FO =1:1. Fasa air dipisahkan dari fasa organik untuk dianalisis kadar $\mathrm{Y}$, Dy dan Gd dengan alat spektrometer pendar sinar-X (MCA ORTEC, $\mathrm{hV}=50 \mathrm{eV}$, sumber ${ }^{241} \mathrm{Am}$, waktu cacah $=300$ detik). Dengan cara yang sama dilakukan juga ekstraksi dengan solven 30\% D2EHPA-Kerosin. Dari hasil percobaan diperoleh kondisi optimum konsentrasi umpan yang dipakai untuk proses selanjutnya.

\section{Variasi waktu pengadukan}

Untuk waktu pengadukan dilakukan dengan cara pengadukan umpan dan ekstraktan divariasi $5 ; 10 ; 15$; 20; 30 menit. Diambil larutan umpan $10 \mathrm{~mL}$ masing-masing dimasukkan ke dalam larutan solven $30 \%$ TBPkerosin juga untuk solven D2EHPA-kerosin, pengadukan pada kecepatan $250 \mathrm{rpm}$, perbandingan FA:FO = 1:1. Fasa air dipisahkan dari fasa organik untuk di analisis kadar Y, Dy dan Gd dengan alat spektrometer pendar sinar-X.

\section{Variasi perbandingan umpan dan solven}

Pada variasi perbandingan umpan dengan solven dilakukan ekstraksi dengan cara diambil larutan umpan $10 \mathrm{~mL}$ masing-masing dimasukkan ke dalam larutan solven $30 \%$ TBP-kerosin juga untuk solven D2EHPA-kerosin, pengadukan pada kecepatan $250 \mathrm{rpm}$, waktu pengadukan 15 menit, perbandingan FA:FO divariasi $1: 0,5 ; 1: 1 ; 1: 1,5 ; 1: 2 ; 1: 3$. Fasa air dipisahkan dari fasa organik untuk dianalisis kadar $\mathrm{Y}$, Dy dan Gd dengan alat spektrometer pendar sinar-X.

\section{HASIL DAN PEMBAHASAN}

\section{Variasi Keasaman Umpan}

Variasi keasaman umpan untuk mengetahui pengaruh keasaman umpan terhadap koefisien distribusi $(K d)$ dan faktor pisah $(F P)$ pada ekstraksi menggunakan solven TBP dan D2EHPA dengan kondisi operasi waktu ekstraksi 15 menit, perbandingan $\mathrm{FA}: \mathrm{FO}=1: 1$ dan kecepatan $=250 \mathrm{rpm}$. Hasil dari variasi konsentrasi keasaman umpan pada ekstraksi Y, Dy, Gd diperoleh nilai koefisien distribusi (Kd) dan faktor pisah (FP) seperti disajikan pada Tabel 1 dan Tabel 2. 
Dari hasil ekstraksi dapat dilihat pada Tabel 1 dan 2 bahwa pada penggunaan keasaman umpan $1 \mathrm{M}$, ekstraksi dengan solven 30\% TBP dalam kerosin, diperoleh faktor pisah terbesar Y-Dy adalah $=4,586$ dan untuk Y-Gd $=0,801$. Menurut Sato [11] pada konsentrasi keasaman relatif tinggi reaksi yang terjadi adalah pembentukan komplek, sedang pada konsentrasi rendah, reaksi yang terjadi adalah pertukaran ion. Ekstraksi dengan solven 30\% D2EHPA dalam kerosin kondisi terbaik diperoleh pada keasaman umpan 0,5 M. Hal ini karena D2EHPA merupakan solven yang bersifat asam sehingga pada kondisi keasaman umpan yang relatif rendah sudah dapat mengambil $Y$ lebih baik dibanding dengan TBP yang cenderung bersifat basa. Untuk solven $30 \%$ D2EHPA dalam kerosin diperoleh harga faktor pisah terbesar Y-Dy $=22,576$ dan Y-Gd $=59,292$.

\section{Variasi Waktu Pengadukan}

Tabel 1. Variasi keasaman umpan dengan solven TBP.

\begin{tabular}{ccccccc}
\hline \multirow{2}{*}{ No. } & Keasaman & \multicolumn{3}{c}{ Koefisien distribusi $(\mathrm{Kd})$} & \multicolumn{2}{c}{ Faktor pisah $(F P)$} \\
\cline { 2 - 7 } & umpan, $\mathrm{M}$ & $\mathrm{Y}$ & $\mathrm{Dy}$ & $\mathrm{Gd}$ & $\mathrm{Y} / \mathrm{Dy}$ & $\mathrm{Y} / \mathrm{Gd}$ \\
\hline 1. & 0,2 & 0,256 & 0,273 & 0,875 & 0,938 & 0,293 \\
2. & 0,5 & 0,343 & 0,388 & 1,009 & 0,884 & 0,340 \\
3. & 1,0 & 0,532 & 0,116 & 0,664 & 4,586 & 0,801 \\
4. & 2,0 & 0,508 & 0,123 & 0,642 & 4,130 & 0,791 \\
5. & 3,0 & 0,432 & 0,175 & 0,787 & 2,469 & 0,549 \\
6. & 4,0 & 0,381 & 0,200 & 0,717 & 1,905 & 0,531 \\
\hline
\end{tabular}

Tabel 2. Variasi keasaman umpan dengan solven D2EHPA.

\begin{tabular}{ccccccc}
\hline \multirow{2}{*}{ No. } & Keasaman & \multicolumn{2}{c}{ Koefisien distribusi $(K d)$} & & \multicolumn{2}{c}{ Faktor pisah $(F P)$} \\
\cline { 3 - 7 } & umpan, $M$ & $\mathrm{Y}$ & $\mathrm{Dy}$ & $\mathrm{Gd}$ & $\mathrm{Y} / \mathrm{Dy}$ & $\mathrm{Y} / \mathrm{Gd}$ \\
\hline 1. & 0,2 & 20,026 & 1,354 & 0,505 & 14,790 & 39,655 \\
2. & 0,5 & 27,452 & 1,216 & 0,463 & 22,576 & 59,292 \\
3. & 1,0 & 23,675 & 1,956 & 0,432 & 12,048 & 51,134 \\
4. & 2,0 & 1,588 & 0,387 & 0,421 & 4,103 & 3,772 \\
5. & 3,0 & 0,919 & 3,217 & 0,416 & 0,286 & 2,209 \\
6. & 4,0 & 0,541 & 2,733 & 0,404 & 0,198 & 1,339 \\
\hline
\end{tabular}

Waktu kontak antara fasa air yang mengandung solut (Y, Gd dan Dy) dengan ekstraktan TBP maupun D2EHPA sebagai fasa organik akan mempengaruhi distribusi solut ke dalam fasa organik. Semakin lama waktu pengadukan akan mengakibatkan semakin banyak solut yang terekstrak ke dalam fasa organik. Tetapi setelah mencapai kesetimbangan, jumlah solut yang terekstrak akan konstan dan waktu tidak berpengaruh lagi. Hubungan antara Kd dan FP dengan waktu pengadukan disajikan pada Tabel 2.

Tabel 3. Variasi waktu pengadukan dengan solven TBP.

\begin{tabular}{ccccccc}
\hline \multirow{2}{*}{ No. } & Waktu & \multicolumn{3}{c}{ Koefisien distribusi (Kd) } & \multicolumn{2}{c}{ Faktor pisah (FP) } \\
\cline { 2 - 6 } & pengadukan, menit & $\mathrm{Y}$ & Dy & Gd & Y/Dy & Y/Gd \\
\hline 1. & 5 & 0,125 & 0,173 & 0,632 & 0,723 & 0,198 \\
2. & 10 & 0,403 & 0,188 & 0,698 & 2,144 & 0,577 \\
3. & 15 & 0,532 & 0,116 & 0,664 & 4,586 & 0,801 \\
4. & 20 & 0,498 & 0,130 & 0,629 & 3,831 & 0,791 \\
5. & 30 & 0,443 & 0,125 & 0,617 & 3,544 & 0,718 \\
\hline
\end{tabular}


Tabel 4. Variasi waktu pengadukan dengan solven D2EHPA.

\begin{tabular}{ccccccc}
\hline \multirow{2}{*}{ No. } & Waktu & \multicolumn{3}{c}{ Koefisien distribusi $(K d)$} & \multicolumn{2}{c}{ Faktor pisah $(F P)$} \\
\cline { 2 - 6 } & pengadukan, menit & $\mathrm{Y}$ & Dy & Gd & Y/Dy & Y/Gd \\
\hline 1. & 5 & 15,125 & 0,835 & 0,632 & 18,114 & 23,932 \\
2. & 10 & 21,403 & 0,988 & 0,598 & 21,663 & 35,791 \\
3. & 15 & 27,452 & 1,216 & 0,463 & 22,576 & 59,292 \\
4. & 20 & 25,498 & 1,130 & 0,621 & 22,565 & 41,060 \\
5. & 30 & 24,994 & 1,145 & 0,617 & 21,835 & 40,509 \\
\hline
\end{tabular}

Dari Tabel 3 dan Tabel 4 dapat dilihat bahwa waktu pengadukan setelah 15 menit $K d$ tidak bertambah atau sudah mengalami kesetimbangan. Dengan bertambahnya waktu kontak reaksi akan semakin sempurna sehingga perpindahan massa dari fasa air ke fasa organik semakin banyak, namun setelah mencapai kesetimbangan jumlah solut yang terekstrak akan tetap dan waktu sudah tidak berpengaruh lagi. Kemudian waktu ini dipakai sebagai dasar untuk optimasi parameter yang lain. Kondisi yang relatif baik dipilih pada waktu pengadukan selama 15 menit dengan nilai faktor pisah $(F P)$ Y-Dy = 22,576 dan Y-Gd = 59,292.

\section{Variasi Perbandingan Umpan dan Solven}

Variasi perbandingan umpan dan solven untuk menentukan kondisi perbandingan umpan dan solven yang relatif baik pada ekstraksi konsentrat itrium. Ekstraksi dilakukan pada keasaman umpan $1 \mathrm{M} \mathrm{HNO}_{3}$ untuk solven 30 \% TBP dan keasaman umpan 0,5 M untuk solven D2EHPA, waktu pengadukan 15 menit, kecepatan pengadukan pada $250 \mathrm{rpm}$, perbandingan volume FA : FO divariasi yaitu $1: 0,5 ; 1: 1 ; 1: 1,5 ; 1: 2$ dan $1: 3$. Hasil penelitian dapat dilihat dalam Tabel 5 . Setelah dilakukan analisis terhadap fasa air dengan spektrometer pendar sinar $\mathrm{X}$, maka diperoleh hasil terbaik pada perbandingan $1: 1$.

Tabel 5. Variasi perbandingan umpan dan solven dengan solven TBP.

\begin{tabular}{ccccccc}
\hline \multirow{2}{*}{ No. } & Perbandingan & \multicolumn{3}{c}{ Koefisien distribusi (Kd) } & \multicolumn{2}{c}{ Faktor pisah (FP) } \\
\cline { 3 - 7 } & umpan dan solvel & $\mathrm{Y}$ & Dy & Gd & Y/Dy & Y/Gd \\
\hline 1. & $1,0: 0,5$ & 0,255 & 0,113 & 0,393 & 2,257 & 0,649 \\
2. & $1,0: 1,0$ & 0,532 & 0,116 & 0,664 & 4,586 & 0,801 \\
3. & $1,0: 1,5$ & 0,502 & 0,136 & 0,694 & 3,691 & 0,723 \\
4. & $1,0: 2,0$ & 0,493 & 0,129 & 0,591 & 3,822 & 0,834 \\
5. & $1,0: 3,0$ & 0,543 & 0,135 & 0,617 & 4,022 & 8,880 \\
\hline
\end{tabular}

Pengaruh perbandingan FA:FO terhadap Koefisien distribusi $(K d)$ dan Faktor Pisah $(F P)$ pada solven D2EHPA dengan kondisi operasi keasaman umpan 0,5 M, waktu ekstraksi 15 menit dan kecepatan $250 \mathrm{rpm}$ dapat dilihat dalam Tabel 6.

Tabel 6. Variasi perbandingan umpan dan solven dengan solven D2EHPA

\begin{tabular}{ccccccc}
\hline \multirow{2}{*}{ No. } & Perbandingan & \multicolumn{3}{c}{ Koefisien distribusi $(K d)$} & \multicolumn{2}{c}{ Faktor pisah $(F P)$} \\
\cline { 3 - 7 } & umpan dan solvel & $\mathrm{Y}$ & $\mathrm{Dy}$ & $\mathrm{Gd}$ & $\mathrm{Y} / \mathrm{Dy}$ & $\mathrm{Y} / \mathrm{Gd}$ \\
\hline 1. & $1,0: 0,5$ & 2,125 & 0,513 & 0,323 & 4,142 & 6,579 \\
2. & $1,0: 1,0$ & 27,452 & 1,216 & 0,463 & 22,576 & 59,292 \\
3. & $1,0: 1,5$ & 20,532 & 1,116 & 0,694 & 18,398 & 29,585 \\
4. & $1,0: 2,0$ & 9,498 & 0,830 & 0,529 & 11,443 & 17,955 \\
5. & $1: 3$ & 5,443 & 0,725 & 0,617 & 7,508 & 8,822 \\
\hline
\end{tabular}


Dari Tabel 5 dan 6 terlihat semakin besar perbandingan fasa air dengan fasa organik, harga koefisien distribusi (Kd) dan faktor pisah $(F P)$ cenderung menurun. Kemungkinan hal ini terjadi karena pembentukan komplek yang terjadi telah mencapai kondisi optimum pada perbandingan FA : FO = $1: 1$ sehingga dengan ditambahnya fasa organik sudah tidak bisa mengambil $Y$ dari fasa air dan hasilnya semakin menurun. Dari percobaan hasil terbaik dipilih pada perbandingan fasa air dengan fasa organik $\mathrm{FA}$ : $\mathrm{FO}=1$ : 1. Ludianto (2010) melakukan optimasi proses ekstraksi dengan konsentrasi $\mathrm{HNO}_{3} 1 \mathrm{M}$ (fasa air), $D_{2}$ EHPA $30 \%$ v/v dalam n-dodekan (fasa organik), perbandingan volume fasa air (FA) dengan volume fasa organik (FO) : $1: 2$, kecepatan pengadukan $300 \mathrm{rpm}$ selama 10 menit diperoleh efisiensi ekstraksi (\%) itrium (Y) sebesar 93,968 \% dengan harga koefisien distribusi $(K d)=15,5782$ dan faktor pisah $(\beta) \mathrm{Y} / \mathrm{La}=83,3437 ; \beta \mathrm{Y} / \mathrm{Ce}=129,0955 ; \beta \mathrm{Y} / \mathrm{Nd}=491,9187$; $\beta Y / S m=168,1274 ; \beta Y / G d=63,6462 ; \beta Y / D y=510,3970$.

\section{KESIMPULAN}

Dari hasil penelitian ekstraksi Y, Dy, Gd dari konsentrat itrium dengan solven TBP dan D2EHPA diperoleh kesimpulan bahwa kondisi terbaik diperoleh pada keasaman umpan $0,5 \mathrm{M}$, waktu ekstraksi 15 menit, perbandingan FA:FO = 1:1. Pada kondisi ini diperoleh harga faktor pisah Y-Dy $=22,576$ dan Y-Gd =59,292.

\section{UCAPAN TERIMA KASIH}

Pada kesempatan ini penulis ucapkan terima kasih kepada pihak manajemen PSTA yang telah memberikan fasilitas dan mendanai penelitian ini. Juga kepada Bapak Dwi Biyantoro, Ibu Suprihati dan almarhum Bapak Mintolo yang telah membantu penelitian ini.

\section{DAFTAR PUSTAKA}

[1] Dwi Biyantoro, "Teknologi Pemisahan Itrium dari Pasir Senotim Untuk Industri", Orasi Pengukuhan Profesor Riset, Bidang Kimia dan Teknologi Proses Bahan BATAN, Yogyakarta, (2008).

[2] A. Amin, "Pemisahan Unsur Samarium dan Ytrium dari Mineral Tanah Jarang dengan Teknik Membran Cair Berpendukung (Supported Liquid Membrane)", Jurnal Rekayasa Kimia dan Lingkungan, Vol. 7, No. 1, 15 23, (2009).

[3] H. B. Bahti, Y. Yayah Mulyasih, Y. Anni Anggraeni, "Extraction and Chromatographic Studies on Rare-Earth Elements (REEs) from their Minerals: the Prospect of REEs Production in Indonesia?", Proceeding of 2nd International Seminar on Chemistry 2011, 421-430, Jatinangor, 24 - 25 November (2011).

[4] P. Koltun AND A. Tharumarajah, "Life Cycle Impact of Rare Earth Elements", Hindawi Publishing Corporation ISRN Metallurgy Vol. 2014, Article ID 907536, 10 pages, (2014).

[5] A. Jordens, Y.P. Cheng, K.E. Waters, "A Review of the Beneficiation of Rare Earth Element Bearing Minerals", J Elsevier, Mineral Engineering, Volume 41, (2013).

[6] C. HURST, "China's Rare Earth Elements Industry: What Can The West Learn?", Institute for the Analysis of Global Security (IAGS), March (2010).

[7] F. Xie, T. A. Zhang, D. Dreisnger, F. Doyle, "A Critical Review on Solvent Extraction of Rare Earths from Aqueous Solutions", Minerals Engineering 56, 10-28, (2014).

[8] P. Satusinprasert, U. Suwanmanee and Rattanaphra, "Separation of Light and Middle-Heavy Rare Earth from Nitrate Medium by Liquid-Liquid Extraction, Kaesetsart Journal (Nat. Sci.) 49: 155-163, (2015).

[9] C.K. Gupta, and N. Krishnamurthy, Extactive Metallurgy of Rare Earths, CRC Press, ISBN 0-415-33340-7, (2005).

[10] HEFA Rare Earth Canada Co. Ltd, Rere Earth Product by Element, http://www.baotourareearth.com/diunduh tanggal 2 Juli 2016, jam 09.00.

[11] Sato, "The Extraction of Uranium (IV), Yttrium(III), and Lantanum(III) from Hydrochloric Solution by Acid Organophosphorus Compounds", Proceeding of the International Symposium on of the International Symposium on Actinide/Lanthanide Separation, Honolulu, USA (1984). 
[12] L.A. Guirguis, R. El Sheikh, N.M. Farag, M.A. Elsayed, M.S., "Solvent Leaching of Total Rare Earth Elements from Phosphate Rocks From Abu-Tartur Plateau, International Journal of Advanced Research, Volume 2, 467-479, Egypt, 2013.

[13] Dwi Biyantoro, Kris Tri, B., dan Suyanti, "Uji Kinerja Asam Nitrat, Asam Sulfat, dan Asam Oksalat dalam Stripping Itrium dari Y-D2EHPA", Prosiding Pertemuan dan Presentasi IImiah - Penelitian Dasar IImu Pengetahuan dan Teknologi Nuklir, Yogyakarta, 2013.

[14] Ludianto Nugroho, "Optimasi Proses Ekstraksi Stripping Itrium (Y) Dari Konsentrat Logam Tanah Jarang Hasil Olah Pasir Senotim", Skripsi, Universitas Negri Yogyakarta, Yogyakarta, 2010. 